\title{
TINJAUAN YURIDIS TERHADAP KEBIJAKAN PEMERINTAH KABUPATEN MAMUJU TERKAIT PENATAANRUANG WILAYAH
}

\author{
Musyafir, Putra Astomo, Fatwansyah Rasyid \\ Universitas Sulawesi Barat \\ Email: musyafir@gmail.com
}

\begin{abstract}
Abstrak
Peraturan Menteri Pekerjaan Umum No.16/PRT/M/2009 tentang Pedoman Penyusunan Rencana Tata Ruang Wilayah Kabupaten merupakan tindak lanjut dari pelaksanaan ketentuan Pasal 11 ayat (2) UU No. 26 tahun 2007 tentang Penataan Ruang Rencana tata ruang wilayah kabupaten sebagaimana dimaksud, ditinjau kembali 1 (satu) kali dalam 5 (lima) tahun.Terkait penulisan ini, maka penulis merumuskan suatu masalah dalam tulisan ini,apa isi dari kebijakan pemerintah terkait tata ruang, tujuan penataan ruang, dan dasar pemerintah Kabupaten Mamuju dalam menyusun Rencana Tata Ruang Wilayah (RTRW) Kabupaten. Adapun metode penulisan yang digunakan dalam penulisan karya ilmiah ini adalah metode penelitian normatif dengan menggunakan pendekatan Undang-Undang (Statute Approach) yang dikaji secara kualitatif, dimana cara yang dilakukan ini bermksudkan agar lebihmudah memahami hasil penulisan yang dianalisis berdasarkan hasil penelitian yang diperoleh dan disusun sistematis, yang kemudian dari hasil analisis tersebut, penulis menarik suatu kesimpulan di dalamnya.
\end{abstract}

\section{Kata kunci: Pemerintah, Kebijakan, Tata Ruang}

\section{A. Pendahuluan}

Aturan dasar atau aturan pokok negara tertuang dalam batang tubuh UUD NRI Tahun 1945 dan hukum dasar tidak tertulis yang sering disebut dengan konvensi ketatanegaraan. Aturan dasar ini merupakan landasan bagi pembentukan undang-undang dan peraturan lain yang lebih rendah. ${ }^{1}$

Berdasarka ketentuan Pasal 1 ayat (3) UUD NRI Tahun 1945, bahwa "Negara Indonesia adalah negara hukum".Sebagai negara hukum, setiap penyelenggaraan urusan pemerintahan haruslah berdasarkan pada hukum yang berlaku (wetmatigheid van bestur). ${ }^{2}$ Berbagai kajian tentang hukum maupun kebijakan publik di Indonesia dewasa ini tidak terlepas dari kontekstualisasi makna negara hukum, sebagaimana yang tertuang dalam ketentuan UUD NRI Tahun 1945.Secara maknawi segala sesuatu yang

\footnotetext{
${ }^{1}$ Ida Zuraida, 2013, Teknik Penyusunan Peraturan Daerah, Jakarta, Sinar Grafika, hlm. 5

${ }^{2}$ Ridwan HR, 2017, Hukum Administrasi Negara, Jakarta: Rajawali Pers, hlm. 17
} 
berhubungan dengan penyelenggaraan negara dan pemerintahan haruslah berlandaskan, berdasarkan, tunduk, dan patuh atas hukum, sebagai barometer untuk mengukur suatu perbuatan atau tindakan baik, telah sesuai atau tidak sesuai dengan ketentuan yang telah disepakati dan ditetapkan. ${ }^{3}$

Ketika ditelaah secara mendalam akar makna dari negara yang menerbitkan sekumpulan aturan maupun segudang kebijakan, masih merupakan sesuatu yang abstrak, tetapi pemerintah itu sendiri adalah sesuatu yang konkret.Sedangkan yang bertindak atau melakukan perbuatan hukum adalah pemerintah, adapun negara sekedar dipandang sebagai wadah, tempat menyelenggarakan pemerintahan. ${ }^{4}$

Walaupun dapat dibedakan, tetapi bukan sesuatu yang setiap saat dapat dipisahkan satu sama lain. Negara tanpa pemerintahan tidak mungkin berfungsi, karena tidak ada instrument (alat) yang bertindak untuk dan atas nama negara. Sebaliknya tidak pernah ada pemerintahan (dalam arti pemrintah negara) selama tidak ada negara, karena eksistensi pemerintah ditentukan oleh eksistensi negara. ${ }^{5}$

Pembentukan peraturan kebijakan diperlukan dalam rangka menjamin ketaat-asasan (konsistensi) tindakan administrasi. ${ }^{6}$ Menurut Pasal 1 angka 9 UU No. 30 tahun 2014 tentang Administrasi Pemerintahan, diskresi adalah putusan dan/atau tindakan yang ditetapkan dan/atau dilakukan oleh pejabat pemerintah untuk mengatasi persoalan konkret yang dihadapi dalam penyelenggaraan pemerintahan dalam hal peraturan perundang-undangan yang memberikan pilihan, tidak mengatur, tidak lengkap atau tidak jelas, dan/atau adanya stagnasi pemerintahan. ${ }^{7}$

Pejabat pemerintah yang menggunakan diskresi harus memenuhi syarat (Pasal 22), sebagai berikut :

1. Sesuai dengan tujuan diskresi sebagaimana dimaksud dalam Pasal 22 ayat (2);

2. Tidak bertentangan dengan ketentuan peraturan perundang-undangan;

3. Sesuai dengan asas-asas umum pemerintahan yang baik (AUPB);

4. Berdasarkan alasan-alasan yang objektif;

5. Tidak menimbulkan konflik kepentingan; dan

6. Dilakukan dengan itikad baik. ${ }^{8}$

Sebagai negara yang menganut desentralisasi dalam penyelenggaraan pemerintahan, sebagaimana diisyaratkan dalam Pasal 18 ayat (1) UUD NRI

\footnotetext{
${ }^{3}$ Luthfi J. Kurniawan/Mustafa Lutfi, 2017, Hukum dan Kebijakan Publik, Malang, Setara Press, Hlm. 1

${ }^{4}$ Ibid., hlm. 3

${ }^{5}$ Ibid.,

${ }^{6}$ Ibid., hlm. 7-8

${ }^{7}$ Eri Yulikhsan, 2016, Keputusan Diskresi dalam Dinamika Pemerintahan, Yogyakarta, CV BUDI UTAMA, hlm. 3

${ }^{8}$ Ibid., hlm. 5
} 
Tahun 1945 "Negara Kesatuan Republik Indonesia dibagi atas daerahdaerah provinsi dan daerah provinsi itu dibagi atas kabupaten dan kota, yang tiap-tiap provinsi, kabupaten, dan kota mempunyai pemerintahan daerah, yang diatur dengan undang-undang." 9

Negara yang mengatur desentralisasi mengandung arti bahwa urusan pemerintahan itu terdiri atas urusan pemerintahan pusat dan urusan pemerintahan daerah. Yang artinya, ada perangkat pemerintah pusat dan ada perangkat pemerintah daerah, yang diberi otonomi yakni kebebasan dan kemandirian untuk mengatur dan mengurus urusan rumah tangga daerah. ${ }^{10}$ Desentralisasi dan otonomi daerah berarti pemerintah lebih banyak memberikan kepercayaan dan pemberdayaan kepada daerah agar mampu berpemerintahan dan berotonomi mengatasi persoalan-persoalan daerahnya. ${ }^{11}$

Peraturan Menteri Pekerjaan Umum No.16/PRT/M/2009 tentang Pedoman Penyusunan Rencana Tata Ruang Wilayah Kabupaten merupakan tindak lanjut dari pelaksanaan ketentuan Pasal 11 ayat (2) UU No. 26 tahun 2007 tentang Penataan Ruang.Pedoman penyusunan rencana tata ruang wilayah kabupaten bertujuan untuk mewujudkan rencana tata ruang wilayah kabupaten yang sesuai dengan ketentuan yang berlaku. ${ }^{12}$

Rencana Tata Ruang Wilayah (RTRW) kabupaten adalah rencana tata ruang yang bersifat umum dari wilayah kabupaten, yang berisi tujuan, kebijakan, strategi penataan ruang wilayah kabupaten, rencana struktur wilayah kabupaten, penetapan kawasan strategis kabupaten, dan ketentuan pengendalian pemanfaatan ruang wilayah kabupaten. ${ }^{13}$ Rencana tata ruang wilayah kabupaten menjadi dasar untuk menerbitkan perizinan lokasi pembangunan dan administrasi pertahanan, dan jangka waktu rencana tata ruang wilayah kabupaten adalah 20 (dua puluh) tahun. Rencana tata ruang wilayah kabupaten sebagaimana dimaksud, ditinjau kembali 1 (satu) kali dalam 5 (lima) tahun. ${ }^{14}$

Dalam kondisi lingkungan strategis tertentu yang berkaitan dengan bencana alam skala besar yang ditetapkan dengan peraturan perundang-undangan dan/atau perubahan batas teritorial negara, wilayah provinsi, dan/atau kabupaten yang ditetapkan dengan undang-undang, rencana tata ruang wilayah kabupaten ditinjau kembali lebih dari 1 (satu) kali dalam 5 (lima)

\footnotetext{
${ }^{9}$ Ridwan HR, Op. cit., hlm. 17

${ }^{10}$ Ibid.,

${ }^{11}$ Miftah Thoha, 2018, Birokrasi Pemerintah Indonesia di Era Reformasi, Jakarta Kencana, hlm. 12

${ }^{12} \mathrm{http}: / /$ www.penataanruang.com/tata-ruang2.html-diakses 10 Februari 2019 Pukul 10:49

${ }^{13}$ Ibid.,

${ }^{14} \mathrm{http}: / /$ www.penataanruang.com/perencanaan-tata-ruang-wilayah-kabupaten.html- diakses 24 mei 2019 pukul 21.00
} 
tahun. Penyelenggaraan penataan ruang adalah kegiatan yang meliputi pengaturan, pembinaan, pelaksanaan, dan pegawasan penataan ruang. ${ }^{15}$

Dan terkait dengan penataan ruang wilayah khususnya di Kabupaten Mamuju dimana peneliti akanmelaksanakan penelitian. Bahwa peneliti merasa perlu adanya kajian terkait Rencana Tata Ruang Wilayah (RTRW) kabupaten yang secara umum merupakan acuan penataan ruang wilayah Kabupaten,dalam melaksanakan penataan ruang wilayah berdasarkan peraturan dan/atau undang-undang yang berlaku. Dari uraian latar belakang, peneliti berinisiatif untuk mengkaji lebih lanjut dalam bentuk skripsi dengan judul "Tinjauan Yuridis Terhadap Kebijakan Pemerintah Kabupaten Mamuju Terkait Penataan Ruang Wilayah"

\section{B. Rumusan Masalah}

Yang menjadi rumusan masalah berdasarkan latar belakang yang telah diuraikan sebelumnya, sebagai berikut :

1. Apa yang menjadi tujuanpenataan ruang dankebijakan yang dikeluarkan olehPemerintah Kabupaten Mamuju terkaitpenataan ruang wilayah kabupaten?

2. Apa yang menjadi landasan yuridisPemerintah Kabupaten Mamuju dalam menyusun RencanaTata Ruang Wilayah Kabupaten?

${ }^{15}$ Ibid., 


\section{Hasil Penelitian dan Pembahasan}

\section{Hasil penelitian}

\section{1) Administrasi dan Geografi Wilayah}

Secara geografis, Kabupaten Mamuju terletak pada posisi 10 39' $110^{\prime \prime}-$ 20 54' 552" Lintang Selatan dan 110 54' 47" - 130 5' 35" Bujur Timur dari Jakarta; (00 0' 0" Jakarta = 1600 48' 28" Bujur Timur Green Wick), dengan luas wilayah $5.056,19 \mathrm{~km}^{2}$, secara administrasi pemerintahan terbagi atas 11 kecamatan, terdiri dari 88 desa, dan 11 kelurahan.

Kecamatan Kalumpang adalah kecamatan terluas dengan luas 1.731,99 $\mathrm{km}^{2}$ atau 34,20\% dari seluruh wilayah Kabupaten Mamuju. Kecamatan Balabalakang luas wilayahnya $21,86 \mathrm{~km}^{2}$ atau $0,43 \%$ merupakan kecamatan terkecil dari Kabupaten Mamuju.

Secara administrasi, Kabupaten Mamuju yang beribukota di Mamuju, berbatasan dengan :

1) Disebelah utara berbatasan dengan Kabupaten Mamuju Tengah;

2) Sebelah timur berbatasan dengan Kabupaten Luwu Utara;

3) Sebelah selatan berbatasan dengan Kabupaten Majene, Kabupaten Mamasa, dan Kabupaten Tana Toraja;

4) Disebelah barat berbatasan dengan Selat Makassar.

\section{2) Ruang Lingkup}

a. Lingkup Wilayah Perencanaan

Wilayah perencanaan RTRW Kabupaten Mamuju meliputi seluruh wilayah Kabupaten Mamuju yang terdiri atas 11(sebelas) kecamatan, diantaranya :

a) Kecamatan Tapalang;

b) Kecamatan Tapalang Barat;

c) Kecamatan Mamuju;

d) Kecamatan Simboro;

e) Kecamatan Kepulauan Balabalakang;

f) Kecamatan Kalukku;

g) Kecamatan Papalang;

h) Kecamatan Tommo;

i) Kecamatan Kalumpang;

j) Kecamatan Bonehau; dan

k) Kecamatan Sampaga.

b. Lingkup Muatan RTRW

Berdasrkan Peraturan Menteri Pekerjaan Umum Nomor 16 Tahun 2009, maka lingkup muatan RTRW Kabupaten Mamuju mencakup :

a) Tujuan, kebijakan dan strategi ruang wilayah kabupaten;

b) Rencana struktur ruang wilayah kabupaten; 
c) Rencana pola ruang wilayah kabupaten;

d) Penetapan kawasan stratehis wilayah kabupaten;

e) Arahan pemanfaatan ruang wilayah;

f) Ketentuan pengendalian pemanfaatan ruang wilayah.

RTRW Kabupaten Mamuju menjadi pedoman untuk :

a) Penyusunan rencana pembangunan jangka panjang daerah;

b) Penyusunan rencana pembangunan daerah;

c) Pemanfaatan ruang dan pengendalian pemanfaatan ruang di wilayah Kabupaten Mamuju;

d) Perwujudan keterpaduan, keterkaitan, dan keseimbangan perkembangan antar wilayah serta keserasian antar sektor di Kabupaten Mamuju;

e) Penetapan lokasi dan fungsi ruang untuk infestasi di Kabupaten Mamuju;

f) Perwujudan keterpaduan rencana pembangunan Kabupaten Mamuju dengan kawasan sekitarnya.

\section{3) Strategi Penataan Ruang}

Strategi penataan ruang wilayah kabupaten merupakan penjabaran kebijakan penataan ruang wilayah kabupaten ke dalam langkah-langkah operasional untuk mencapai tujuang yang telah ditentukan, antara lain sebagai berikut :

a. Strategi peningkatan peran dan fungsi kawasan perkotaan sebagai pusat-pusat pertumhan di Kabupaten Mamuju;

b. Strategi pengembangan pusat pertubuhan ekonomi secara merata dan berhirarki di Kabupaten Mamuju;

c. Strategi pengembangan sentra-sentra produksi pertanian, perkebunan, peternakan, perikanan, dan kelautan sebagai komoditas unggulan di Kabupaten Mamuju;

d. Strategi pengembangan disektor non pertanian yang terpadu dan berbasis kepada masyarakat di Kabupaten Mamuju;

e. Strategi pengembangan, dan peningkatan kualitas infrastruktur yang menjangkau seluruh wilayah Kabupaten Mamuju;

f. Strategi pengembangan kawasan yang memiliki nilai strategis untuk pemanfaatan sumber daya alam di ruang darat, ruang laut, dan ruang udara, termasuk ruang bawah muka bumi di Kabupaten Mamuju;

g. Strategi perlindungan kawasan lindung dan konservasi yang ada untuk mempertahankan ekosistem yang berbasis pada mitigasi bencana lingkungan di Kabupaten Mamuju; dan

h. Strategi peningkatan fungsi kawasan untuk pertahanan dan keamanan di Kabupaten Mamuju. 


\section{4) Rencana Struktur Ruang}

a. Rencana Umum

Rencana struktur tata ruang wilayah Kabupaten Mamuju disusun untuk kurun waktu 20 tahun mendatang (2015-2035) meliputih pengembangan sistem pusat-pusat kegiatan, pengembangan sistem jaringan prasarana utama (sistem jaringan transportasi), dan pengembangan sistem jaringan prasana lainnya (sistem jaringan energi, pengembangan sistem jaringan, sistem telekomunikasi, dan dan pengembangan sistem jaringan sumberdaya air).

b. Rencana pengembangan pusat-pusat kegiatan, yang terdiri atas :

a) Pusat Kegiatan Nasional Provinsi (PKNp);

b) Pusat Kegiatan Lokal Provinsi (PKLp);

c) Pusat Pelayanan Kawasan (PPK) merupakan kawasan perkotaan yang berfungsi untuk melayani kegiatan skala kecamatan atau beberapa desa; dan

d) Pusat Pelayanan Lingkungan (PPL) merupakan pusat pemukiman yang berfungsi untuk melayani kegiatan skala antar desa.

c. Rencana pengembangan sistem jaringan transportasi, terdiri atas :

a) Sitem jaringan transportsi darat;

b) Rencana sistem jaringan perkeretaapian;

c) Rencana sistem jaringan transportasi laut; dan

d) Rencana sistem jaringan transportasi udara.

d. Rencana pengembangan sistem jaringan energi

e. Rencana pengembangan sistem jaringan telekomunikasi

f. Rencana pengembangan sistem jaringan sumberdaya air

g. Rencana sistem prasarana pengelolaan lingkungan

\section{5) Ketetapan Kawasan Strategis Kabupaten}

Dalam konteks Kawasan Strategis Kabupaten (KSK), dilakukan suatu kajian secara spesifik pada kawasan-kawasan strategis di Kabupaten Mamuju,kawasan strategis kabupaten yang dimaksud adalah wilayah yang penataan ruangnya diproritaskan karena mempunyai pengaruh sangat penting dalam lingkup kabupaten terhadap ekonomi, sosial, budaya, dan/atau lingkungan.

a. Kawasan yang memiliki nilai strategis dari sudut kepentingan ekonomi terdiri dari :

a) Kawasan Strategis Matabe (Mamuju, tampapadang dan BelangBelang);

b) Kawasan Perkotaan (PKLp) Papalang;

c) Kawasan strategis Agropolitan Kalukku;

d) Kawasan Minapolitan Mamuju Boda dan Mala'bi; dan 
e) Kawasan pertambangan Mineral Logam Kalumpang.

b. Kawasan yang memiliki nilai strategis dari sudut kepentingan sosial budaya antara lain :

a) Kawasan Masjid Raya Sauda;

b) Kawasan Situs Minanga Sipakko terletak di Kecamatan Kalumpang;

c) Kawasan Rumah Adat Mamuju di Kecamatan Mamuju;

d) Kawasan Pendidikan di Kota Mamuju; dan

e) Kawasan Wisata Pulau Karampuang.

c. Kawasan Strategis dari sudut kepentingan pendayagunaan sumber daya alam dan/atau teknologi tinggi, terdiri atas :

a) Kawasan Pembangkit Listrik Tenaga Air (PLTA) Karama;

b) Kawasan Pembangkit Listrik Tenaga Uap (PLTU) Kalukku;

c) Kawasan Bendungan Tommo;

d) Kawasan pertambangan minyak dan gas bumi Blok Malunda, Blok Budong-Budong, Blok Karama, dan Blok Balabalakan; dan

e) Kawasan pertabangan panas bumi di Kecamatan Kalumpang, Kecamatan Kalukku, dan Kecamatan Tapalang.

d. Kawasan yang memiliki nilai strategis dari sudut kepentingan fungsi dan daya dukung lingkungan hidup, terdiri atas :

a) Kawasan suaka alam Bonehau dan Kalumpang;

b) Kawasan pantai berhutang mangrup di Kecamatan Kalukku;

c) Kawasan taman nasional Ganda Dewasa;

d) Kawasan taman wisata alam laut Balabalakan; dan

e) Kawasan pesisir dan pulau-pulau kecil di Kecamatan Kepulauan Balabalakan.

6) Partisipasi Masyarakat (Hak, Kewajiban, dan Peran Masyarakat)

Dalam proses penataan ruang setiap orang/warga masyarakat berhak untuk :

a. Mengetahui secara terbuka rencana umum tata ruang dan rencana rinci tata ruang;

b. Menikmati manfaat ruang dan/atau pertambahan nilai ruang sebagai akibat dari penataan ruang;

c. Memperoleh pergantian yang layak atas kondisi kerugian yang dialaminya sebagai akibat dari pelaksanaan kegiatan pembangunan yang sesuai dengan tata ruang;

d. Mengajukan keberatan kepada pejabat berwenang terhadap pembangunan yang tidak sesuai dengan rencana tata ruang di wilayahnya; 
e. Mengajukan tuntutan pembatalan izin dan tuntutan penghentian pembangunan yang tidak sesuai dengan rencana tata ruang kepada pejabat yang berwenang;

f. Mengajukan gugatan ganti kerugian kepada pemerintah dan/atau pemegangizin apabila kegiatan pembangunan yang tidak sesuai dengan rencana tata ruang menimbulkan kerugian.

Berdasarkan peraturan perundang-undangan yang berlaku dalam melaksanakan peran masyarakat dalam pemanfaatan ruang, masyarakat wajib :

a. Menaati rencana tata ruang yang telah ditetapkan;

b. Memanfaatkan ruang sesuai dengan izin pemanfaatan ruang dari pejabat yang berwenang;

c. Mematuhi ketentuan yang ditetapkan dalam persyaratan izin pemanfaatan ruang;

d. Memberikan akses terhadap kawasan yang oleh ketentuan peraturan perundang-undangan dinyatakan sebagai milik umum.

Peran masyarakat dalam penataan ruang di daerah dilakukan antara lain melalui :

a. Partisipasi dalam penyusunan rencana tata ruang;

b. Partisipasi dalam pemanfaatan ruang; dan

c. Partisipasi dalam pengendalian pemanfaatan ruang.

Bentuk peran masyarakat pada tahap perencanaan tata ruang dapat berupa :

a. Memberikan mesukan mengenai :

a) Penentuan arah pengembangan wilayah;

b) Potensi dan masalah pembangunan;

c) Perumusan rencana tata ruang; dan

d) Penyusunan rencana struktur dan pola ruang.

b. Menyampaikan keberatan terhadap rancangan rencana tata ruang; dan

c. Melakukan kerja sama dengan pemerintah daerah dan/atau sesame unsur masyarakat.

Bentuk peran masyarakat dalam pemanfaatan ruang dapat berupa :

a. Melekukan kegiatan pemanfaatan ruang yang sesuai dengan kearifan local dan rencana tata ruang yang telah ditetapkan;

b. Menyampaikan masukan mengenai kebijakan pemanfaatan ruang;

c. Memberikan bantuan teknik, keahlian, dan/atau dana dalam pengelolaan pemanfaatan ruang;

d. Meningkatkan efisiensi, efektifitas, dan keserasian dalam pemanfaatan ruang darurat, ruang laut, ruang udara, dan ruang di 
dalam bumi dengan menperhatikan kearifan lokal serta sesuai dengan peraturan perundang-undangan;

e. Melakukan kerjasama pengelolaan ruang dengan pemerintah, pemerintah daerah, dan/atau pihak lainnya yang bertanggungjawab untuk pencapaian tujuan penataan ruang;

f. Menjaga fungsi pertahanan serta memelihara dan meningkatkan kelestarian fungsi lingkungan dan sumber daya alam;

g. Melakukan usaha investasi dan/atau jasa keahlian.

Bentuk peran serta masyarakat dalam pengendalian pemanfaatan ruang dapat berupa :

a. Memberikan masukan mengenai ketentuan zonasi, perizinan, pemberian insentif dan disinsentif serta pengenaan sanksi;

b. Turut serta memantau dan mengawasi pelaksanaan kegiatan pemanfaatan ruang, rencana tata ruang yang telah ditetapkan, dan pemenuhan standar pelayanan minimal di bidang penataan ruang;

c. Melaporkan kepada instansi/pejabat dalam hal menemukan kegiatan pemanfaatan ruang yang melanggar rencana tata ruang yang telah ditetapkan dan adanya indikasi kerusakan dan/atau pencemaran lingkungan, tidak memenuhi pelayanan minimal dan/atau masalah yang terjadi di masyarakat dalam penyelenggaraan penataan ruang;

d. Mengajukan keberatan terhadap keputusan pejabat publik yang dipandang tidak sesuai dengan rencana tata ruang.

\section{Pembahasan}

1) Tujuan Penataan Ruang Dan Kebijakan Yang Dikeluarkan Oleh Pemerintah Kabupaten Mamuju Terkait Penataan Ruang Wilayah Kabupaten

a. Tujuan Penataan Ruang Wilayah Kabupaten Mamuju

Penataan ruang Kabupaten Mamuju bertujuan untuk mewujudkan ruang wilayah Kabupaten Mamuju yang aman, nyaman, produktif, dan berkelanjutan, berbasis pada perdagangan dan jasa, pariwisata, perkebunan, pertanian, perikanan, dan kelautan yang berdaya saing tinggi didukung oleh sistem transportasi yang terpadu menuju masyarakat Mamuju yang sejahterah.

b. Kebijakan Penataan Ruang Wilayah Kabupaten Mamuju

Kebijakan penataan ruang wilayah kabupaten merupakan arah tindakan yang harus ditetapkan untuk mencapai tujuan penataan ruang wilayah kabupaten. Berdasarkan tujuan penataan ruang wilayah, maka Pemerintah Kabupaten Mamuju mengeluarkan kebijakan terkait penataan ruang wilayah, sebagai berikut : 
a) Peningkatan peran dan fungsi kawasan perkotaan sebagai pusatpusat pertubuhan;

b) Pengembangan pusat pertubuhan ekonomi secara merata dan berhirarki;

c) Pengembangan sentra-sentra produksi perkebunan, pertanian, perikanan, dan kelautan sebagai komoditas unggulan;

d) Pengembangan disektor non pertanian yang terpadu dan berbasis kepada masyarakat;

e) Pengembangan, dan peningkatan kualitas infrastruktur yang menjangkau seluruh wilayah Kabupaten Mamuju;

f) Pengemangan kawasan yang memiliki nili strategis untuk pemanfaatan sumber daya alam di ruang darat, ruang laut, dan ruang udara, termasuk ruang bawa muka bumi;

g) Perlindungan pada kawasan lindung dan konservasi yang ada untuk mempertahakan keseimbangan ekosistem yang berbasis pada mitigasi bencana; dan

h) Peningkatan fungsi kawasan untuk pertahanan dan keamanan Negara.

\section{Kebijakan Arahan Pemanfaatan Ruang}

Arahan pemanfaatan ruang wilayah kabupaten ini merupakan perwujudan kebijakan terkait rencana tata ruang yang dijabarkan ke dalam indikasi program utama penataan/pengembangan wilayah kabupaten dalam jangka waktu perencanaan 5 (lima) tahunan sampai akhir tahun perencanaan (20 tahun). Arahan pemanfaatan ruang wilayah kabupaten berfungsi :

a. Sebagai acuan bagi pemerintah dan masyarakat dalam pemerograman penataan/pengembangan wilayah kabupaten.

b. Sebagai arahan untuk sektor dalam penyusunan program (besaran, lokasi, sumber pendanaan, instansi pelaksana, dan waktu pelaksanaan).

c. Sebagai acuan bagi masyarakat dalam melakukan investasi.

Penataan ruang wilayah Kabupaten Mamuju dilakukan dengan menyusun indikasi program utama yang sinergis dengan RTRW Provinsi Sulawesi Barat dan RTRWNasional. Yang secara umum programprogram utama berisi :

a. Perwujudan Struktur Ruang Wilayah Kabupaten

a) Perwujudan sistem perkotaan kabupaten;

b) Perwujudan sistem transportasi kabupaten;

c) Perwujudan jaringan prasarana wilayah lainnya; dan

d) Perwujudan kawasan andalan kabupaten. 
b. Perwujudan Pola Ruang Kabupaten

a) Perwujudan kawasan lindung; dan

b) Perwujudan kawasan budidaya.

c. Perwujudan pengembangan kawasan strategis kabupaten.

2) Landasan YuridisPemerintah Kabupaten Mamuju Dalam Menyusun Rencana Tata Ruang WilayahKabupaten

Terkait dengan penyusunan rencana tata ruang wilayah Kabupaten, yang dimana penyusunan Rencana Tata Ruang Wilayah (RTRW) khususnya di Kabupaten Mamuju berpedoman dan/atau mengacu padaBUKU RTRW Kabupaten Mamuju yang merupakan pedoman dan/atau acuan dalam penyusunanRANPERDA (RTRW) Kabupaten Mamujuyangmerupakan dasar atau acuan dalam pelaksanaan penataan ruang wilayah kabupaten. Pemerintah Kabupaten Mamujumenyusun BUKU RTRW Kabupaten Mamuju yang dimana di dalamnya mengatur tentang tujuang, kebijakan, strategi penataan ruang wilayah kabupaten.Dimana hal tersebut dijadikan tolak ukurdalam penyusunan rencana tata ruang wilayah kabupaten.

PenyusunanRencana Tata Ruang Wilayah (RTRW) Kabupaten Mamuju yang berpedoman dan/atau mengacu pada BUKU RTRW Kabupaten Mamujuyang secara hukum,penyusunan rencana tata ruang wilayah Kabupaten Mamuju telahdisusun berdasarkandan/atau sesuai dengan peraturan-peraturan dan/atau perundang-undangan yang berlaku terkait penataan ruang wilayah, berikut:

a. Undang-Undang Nomor 26 Tahun 2007 tentang Penataan Ruang, sebagai berikut :

Pasal 6 ayat (2) yang dimaksud "komplementer" adalah bahwa penataan ruang wilayah nasional, penataan ruang wilayah provinsi, dan penataan ruang wilayah kabupaten/kota saling melengkapi satu sama lain, bersinergi, dan tidak terjadi tumpang tindih kewenangan dalam penyelenggaraannya.

Pasal 11 ayat (1) bahwa wewenang pemerintah daerah kabupaten/kota dalam penyelenggaraan penataan ruang meliputi, pengaturan, pembinaan, dan pengawasan terhadap pelaksanaan penataan ruang wilayah kabupaten/kota dan kawasan strategis kabupaten/kota; pelaksanaan penataan ruang wilayah kabupaten/kota; pelaksanaan penataan ruang kawasan strategi kabupaten/kota; dan kerja sama penataan ruang antar kabupaten/kota.

Pasal 11 ayat (2) mengamanatkan pemerintah daerah kabupaten berwenang dalam melaksanakan penataan ruang wilayah kabupaten 
yang meliputi perencanaan tata wilayah kabupaten, pemanfaatan ruang wilayah kabupaten, dan pengendalian pemanfaatan ruang wilayah kabupaten.

b. Peraturan Menteri Pekerjaan Umum Nomor 16 Tahun 2009 tentang Pedoman Penyusunan Rencana Tata Ruang Wilayah Kabupaten, sebagai berikut :

Pasal 2 yang berbunyi" Pedoman Penyusunan Rencana Tata Ruang Wilayah Kabupaten dimaksudkan sebagai acuan dalam kegiatan penyusunan rencana tata ruang wilayah kabupaten oleh pemenrintah daerah kabupaten dan para pemangku kepentingan lainnya".

Pasal 3 yang berbunyi "Pedoman Penyusunan Rencana Tata Ruang Wilayah Kabupaten bertujuan untuk mewujudkan rencaca tata ruang wialayah kabupaten sesuai dengan ketentuan dalam UU No. 26 Tahun 2007 tentang Penataan Ruang."

Pasal 4 yang berbunyi "ruang lingkup Peraturan Menteri ini memuat ketentuan teknis rencana tata ruang wilayah kabupaten serta proses dan prosedur penyusunan rencana tata ruang wilayah kabupaten."

Namun terkaitdengan pelaksanaan penataan ruang wilayahkhususnya di Kabupaten Mamuju yang harusnya memiliki peraturan daeran (RTRW) mengingat Kabupaten Mamuju merupakan Ibukota Provinsi Sualewesi Barat yang terbentuk sejak5 Oktober 2004, akan tetapi pada kenyataannya sampai saat ini pemerintah Kabupaten Mamuju belum memiliki peraturan daerah (RTRW) sebagai dasar pelaksanaan penataan ruang wilayah Kabupaten.

Keterbatasan pemerintah Kabupaten Mamuju dalam melaksanakan penataan ruang wilayah dikarenakanRTRW Kabupaten Mamuju belum ada dan dasar pelaksanaan penataan ruang wilayah Kabupaten Mamuju secara umum sampai saat ini belum jelas. Dan keberadaan RTRW Kabupaten Mamujuselaku Ibukota Provinsi Sulawesi Barat sampai saat ini masih dalam bentuk rancangan dan/atau masih dalam pembahasan di DPRD Kabupaten Mamuju seperti yang disampaikan oleh Kasubag Umum dan Kepegawaian bapak Erick Ady Novendra.

Dan yang menjadi salah satu alasan kendala pemerintah Kabupaten Mamuju mengapa sampai saat ini pembahasan Rancangan Peraturan Daerah Kabupaten Mamuju dalam hal ini RTRW belum selesai dikarenakan masih banyaknya berubahan-perubahan isi RANPERDA RTRW akibat adanya pemetaan wilayah sebelumnya.

\section{Pentup}


1. Bahwaterkait denganpenyusunanRencana TataRuang Wilayah (RTRW) Kabupaten Mamuju, yang acuan dan/atau pedoman pemerintah Kabupaten Mamuju merujuk pada BUKU RTRW yang di dalamnya memuat tujuan, kebijakan, dan strategi penataan ruang wilayah kabupatenyang disusun oleh pemerintah kabupatenberdasarkan peraturan-peraturan dan/atau perundangundangan yang berlakudan juga berdasarkan kondisi dan/atau keadaan wilayah Kabupaten Mamuju.

Dengan kata lain, bahwa acuan dan/atau pedoman pemerintah Kabupaten Mamuju dalam menyusunrencana tata ruang wilayah (RTRW)berpedoman pada BUKU RTRW yang penyusunannya tidak terlepas dari rencana tata ruang wialayah Nasional dan rencana tata ruang wilayah Provinsi berdasarkan dan/atau sesuai dengan peraturan atau perundang-undangan yang berlaku sebagai berikut :

1) Undang-Undang Nomor 26 Tahun 2007 tentang Penataan Ruang; dan

2) Peraturan Menteri Pekerjaan Umum Nomor 16 Tahun 2009 tentang Pedoman Penyusunan Rencana Tata Ruang Wilayah Kabupaten.

2. Mengapa kemudian perlu adanya acuan dan/atau pedomanpenyusunan rencana tata ruang wilayah kabupaten, dikarenakan wilayah kabupaten yang penataan ruangnya diprioritaskan, karena mempunyai pengaruh sangat penting dalam lingkup kabupaten itu sendiri terhadap ekonomi, social budaya, dan/atau lingkungan, dan juga penentuan kawasan strategis kabupaten lebih bersifat indikatif.

Inilah yang menjadi alasan mengapa pemerintah kabupaten perlu memiliki pedoman atau acuan yang jelas dalam menyusun Rencana Tata Ruang Wilayah (RTRW) Kabupaten, karena peraturan daerah(RTRW) kabupaten merupakan dasar dan/atau acuanpemerintahdidalam melaksanakan penataan ruang wilayahberdasarkanketentuan-ketentuan yang berlaku. 


\section{Daftar Pustaka}

EriYulikhsan, 2016, Keputusan Diskresi dalam Dinamika Pemerintahan, Yogyakarta: CV BUDI UTAMA.

Ida Zuraida, 2013, TeknikPenyusunanPeraturan Daerah, Jakarta: Sinar Grafika.

Luthfi J. Kurniawan/Mustafa Lutfi, 2017, HukumdanKebijakanPublik, Malang: Setara Press.

MiftahThoha, 2018, BirokrasiPemerintah Indonesia di Era Reformasi, Jakarta: Kencana.

Ridwan HR, 2017, Hukum Administrasi Negara, Jakarta:Rajawali Pers.

http://www.penataanruang.com/tata-ruang2.html- diakses 10 Februari 2019 Pukul $10: 49$

http://www.penataanruang.com/perencanaan-tata-ruang-wilayah-kabupaten.htmldiakses 24 mei 2019 pukul 21.00 